\title{
IMPLIKASI KEWAJIBAN PELAKSANAAN PATEN TERHADAP PENYELENGGARAAN ALIH TEKNOLOGI
}

\section{IMPLICATIONS OF OBLIGATIONS FOR PATENT IMPLEMENTATION IN TECHNOLOGY TRANSFER PROCESSES}

\author{
Radhyca Nanda Pratama \\ Ilmu Hukum, Universitas Negeri Surabaya, Jl. Ketintang, Gayungan, Kota Surabaya \\ radhycanp@gmail.com \\ Dilla Nurfiana Astanti \\ Ilmu Hukum, Universitas Negeri Surabaya, Jl. Ketintang, Gayungan, Kota Surabaya \\ dillanurfianaa@gmail.com \\ Muh. Ali Masnun \\ Ilmu Hukum, Universitas Negeri Surabaya, Jl. Ketintang, Gayungan, Kota Surabaya \\ alimasnun@unesa.ac.id
}

\begin{abstract}
Abstrak
Teknologi memiliki peran sentral dalam akselerasi pembangunan sebuah negara. Kebutuhan terhadap teknologi diupayakan melalui proses alih teknologi. Tujuan dari penelitian ini adalah untuk menganalisis implikasi kewajiban pelaksanaan paten terhadap penyelenggaraan alih teknologi dikaitkan dengan asas hukum benda yakni droit de suite. Penelitian ini menggunakan metode penelitian hukum dengan menggunakan bahan hukum primer dan sekunder. Pendekatan yang digunakan adalah pendekatan perundang-undangan (statue approach) dan pendekatan konsep (conceptual approach) untuk kemudian dianalisis secara mendalam dengan metode preskriptif. Hasil penelitian menunjukkan bahwa ketentuan sebagaimana dimaksud dalam Pasal 20 UU Paten memerlukan pengecualian khusus bagi pemegang paten yang berbentuk Lembaga Ilmu Pengetahuan dan Teknologi agar dapat melakukan kewajiban terkait membuat produk atau menggunakan proses di Indonesia untuk menunjang transfer teknologi. Rekomendasi dari penelitian ini adalah perlu adanya pengecualian terhadap Pasal 20 UU Paten dengan memberi ruang kepada pemegang paten asing untuk tidak serta merta memenuhi kewajiban dalam Pasal 20 UU Paten tersebut atau mengadakan perubahan (amandemen) terhadap ketentuan tersebut.
\end{abstract}

Kata Kunci: Implikasi, Paten, Alih Teknologi

\begin{abstract}
Technology has a central role in accelerating the development of a country. The need for technology is pursued through a technology transfer process. The purpose of this study was to analyze the implications of patent obligations on the implementation of technology transfer in relation to the principle of property law, namely the droit de suite. This research uses legal research methods using primary and secondary legal materials. The approach used is a statutory approach) and a conceptual approach to be analyzed in depth with a prescriptive
\end{abstract}


method. The results of the research show that the provisions referred to in Article 20 of the Patent Law require special exemptions for patent holders in the form of Institute of Science and Technology in order to carry out obligations related to making products or using processes in Indonesia to support technology transfer. The recommendation from this research is that there is a need for an exception to Article 20 of the Patent Law, by providing room for foreign patent holders not to immediately fulfill the obligations in Article 20 of the Patent Law or to make amendments (amendments) to these provition.

Keywords : Implications, Patents, Technology Transfer.

\section{A. Pendahuluan}

Ilmu pengetahuan dan teknologi memiliki peran sangat penting dalam pembangunan di sebuah negara. Hal tersebut sangat beralasan, karena melalui kemajuan iptek, manusia dapat mendayagunakan kekayaan dan lingkungan alam ciptaan Tuhan Yang Maha Esa untuk menunjang kesejahteraan dan meningkatkan kualitas kehidupannya. ${ }^{1}$ Kemajuan di bidang ilmu pengetahuan dan teknologi menjadi hal penting dalam akselerasi sebuah negara di tengah arus globalisasi yang makin pesat. Bagaimana negara-negara yang tergolong maju karena ditunjang dengan kemajuan di bidang teknologi yang dimilikinya, sehingga mampu mengekspor berbagai komoditi yang memiliki nilai ekonomi tinggi.

1 Kementerian Riset, Teknologi, Dan Pendidikan Tinggi Republik Indonesia, Naskah Akademik Rancangan Undang-Undang Tentang Sistem Nasional IImu Pengetahuan Dan Teknologi, (Jakarta: Kemenristekdikit, 2017), hlm. 2
Teknologi tak pelak menjadi kebutuhan primer di semua negara.

Pemanfaatan teknologi perlu ditunjang dengan sumber daya manusia yang handal, terampil, dan profesional di samping juga yang tidak kalah penting adalah peran negara (intervensi) melalui pembentukan regulasi yang mendorong teknologi. Indonesia sebagai negara hukum telah mengakomodir kebutuhan teknologi tersebut dan mengakuinya sebagai hak asasi manusia sebagaimana telah diatur dalam ketentuan Pasal 28C ayat (1) UUD NRI Tahun 1945 yang ketentuan tersebut berbunyi:

"Setiap orang berhak mengembangkan diri melalui kebutuhan dasarnya, berhak mendapat pendidikan dan memperoleh manfaat dari ilmu pengetahuan dan teknologi seni dan budaya, demi meningkatkan kualitas hidupnya dan demi kesejahteraan umat manusia."

Paten sebagai salah satu jenis hak kekayaan intelektual di bidang teknologi yang dilindungi melalui instrumen hukum nasional maupun internasional. 
Berdasarkan ketentuan Pasal 1 angka 1 UU Paten dinyatakan bahwa :

"Paten adalah hak ekslusif yang diberikan oleh negara kepada inventor atas hasilnya invensi di bidang teknologi untuk jangka waktu tertentu melaksanakan sendiri invensi tersebut atau memberikan persetujuan kepada pihak lain untuk melaksanakannnya."

Berdasarkan definisi UU Paten tersebut, maka jelas dapat diartikan bahwa perlindungan atas paten sebagai bentuk pencegahan (preventif) agar pihak lain tidak mengeksploitasi secara komersial suatu invensi, dengan demikian inventor atau pemegang paten dapat mengambil manfaat ekonomi atas invensi tersebut. ${ }^{2}$ Perlindungan paten melalui pemberian hak eksklusif pada dasarnya juga digunakan sebagai dasar untuk mendorong atau meningkatkan gairah invensi yang dihasilkan. Indonesia sebagai negara berkembang yang hingga saat ini masih menggunakan produk-produk teknologi dari luar negeri yang mana konsekuensinya kita perlu membayar mahal. Lihat statistik pendaftaran peten berdasarkan negara pemohonnya.

Tabel 1. Pendaftaran Paten Berdasarkan Negara Pemohon Tahun 2017-2018

2 Direktorat Jenderal Kekayaan Intelektual, Modul Kekayaan Intelektual di Bidang Paten, (Jakarta : DJKI Kemenkumham, 2019), hlm.2.

\begin{tabular}{lcccc}
\hline \multirow{2}{*}{$\begin{array}{c}\text { Nama } \\
\text { Negara }\end{array}$} & \multicolumn{2}{c}{ Permohonan } & \multicolumn{2}{c}{ Registrasi } \\
\cline { 2 - 5 } & $\mathbf{2 0 1 7}$ & $\mathbf{2 0 1 8}$ & $\mathbf{2 0 1 7}$ & $\mathbf{2 0 1 8}$ \\
\hline Australia & 80 & 68 & 68 & 72 \\
\hline Austria & 30 & 37 & 34 & 47 \\
\hline Belgium & 71 & 88 & 51 & 50 \\
\hline Bermuda & 3 & 1 & 8 & 4 \\
\hline Brazil & 16 & 3 & 10 & 6 \\
\hline Canada & 50 & 45 & 36 & 45 \\
\hline Cayman Islands & 3 & 107 & 8 & 3 \\
\hline Chile & 2 & 1 & 6 & 1 \\
\hline China & 492 & 571 & 145 & 202 \\
\hline Colombia & - & 1 & 6 & 1 \\
\hline Chyprus & 2 & 1 & - & 1 \\
\hline Czech Republic & 6 & 5 & 5 & 1 \\
\hline Denmark & 55 & 55 & 42 & 58 \\
\hline EUIPO & - & - & - & - \\
\hline Eurasia Patent & - & - & - & - \\
Organization & & & & - \\
\hline European \\
Patent Office
\end{tabular}

\begin{tabular}{lcccc}
\hline Finland & 80 & 87 & 52 & 92 \\
\hline France & 235 & 236 & 189 & 198 \\
\hline Germany & 399 & 446 & 320 & 305 \\
\hline Greece & 3 & 1 & 1 & 1 \\
\hline Hong Kong & 13 & 7 & 7 & 6 \\
\hline Hungary & 4 & 4 & 7 & 6 \\
\hline Iceland & 1 & 1 & - & - \\
\hline India & 89 & 120 & 61 & 66 \\
\hline Indonesia & 2272 & 2842 & 578 & 796 \\
\hline Italia & 87 & 72 & 67 & 81 \\
\hline Japan & 2407 & 2606 & 1451 & 2216 \\
\hline Liechtenstein & - & - & - & 1 \\
\hline Luxemburg & 24 & 10 & 15 & 16 \\
\hline Malaysia & 49 & 65 & 41 & 47 \\
\hline Mexsico & 7 & 4 & 14 & 7 \\
\hline Netherlands & 275 & 322 & 211 & 240 \\
\hline New & 14 & 8 & 8 & 7
\end{tabular}

Zealand

\begin{tabular}{lcccc}
\hline Norway & 17 & 21 & 27 & 33 \\
\hline Republic of & 386 & 584 & 208 & 299
\end{tabular}

Korea

\begin{tabular}{lllll}
\hline Singapore & 84 & 79 & 38 & 50 \\
\hline
\end{tabular}




\begin{tabular}{lcccc}
\hline $\begin{array}{l}\text { South } \\
\text { Korea }\end{array}$ & 19 & 13 & 21 & 15 \\
\hline Spain & 21 & 27 & 17 & 30 \\
\hline Sweden & 103 & 119 & 87 & 105 \\
\hline Swithzerland & 381 & 375 & 266 & 278 \\
\hline $\begin{array}{l}\text { Taiwan, } \\
\text { Province of } \\
\text { China }\end{array}$ & 98 & 147 & 48 & 67 \\
\hline Thailand & 26 & 40 & 10 & 10 \\
\hline Turkey & 18 & 5 & 4 & 6 \\
\hline $\begin{array}{l}\text { United Arab } \\
\text { Emirates }\end{array}$ & 2 & 13 & - & 3 \\
\hline $\begin{array}{l}\text { United } \\
\text { Kingdom }\end{array}$ & 172 & 219 & 104 & 112 \\
\hline $\begin{array}{l}\text { United States } \\
\text { of America }\end{array}$ & 1574 & 1673 & 958 & 1026 \\
\hline Vietnam & - & 1 & - & 2 \\
\hline $\begin{array}{l}\text { Virgin Islands } \\
\text { British) }\end{array}$ & 1 & 5 & 10 & 8 \\
\hline Sumber Data & Laporan Tahunan DJKI
\end{tabular}

Sumber Data : Laporan Tahunan DJKI Tahun 2018

Berdasarkan Tabel 1, permohonan dan registrasi paten di Indonesia sebagai negara berkembang tergolong cukup tinggi apabila dibandingkan dengan jumlah permohonan dan registrasi paten di negara lain. Tinggi rendahnya permohonan paten disuatu negara dapat menjadi catatan penting terkait kinerja dan aktivitas riset dan teknologi yang dilakukan oleh negara yang bersangkutan. Perbandingan jumlah permohonan serta registrasi paten pada negara maju dan negara berkembang menunjukkan bahwa paten dapat menjadi salah satu indikator dalam menentukan serta mengkaji kinerja ekonomi dan teknologi pada suatu negara ${ }^{3}$.

Pendaftaran paten luar negeri di Indonesia pada tahun 2018 mencapai jumlah 14.369 permohonan sedangkan paten dalam negeri berjumlah 3.635 permohonan ${ }^{4}$. Artinya, permohonan paten yang dilakukan oleh pihak asing (luar negeri) di Indonesia jauh lebih tinggi apabila dibandingkan dengan permohonan paten yang dilakukan oleh domestik.

Memperbincangkan permohonan Paten, maka selalu berkaitan erat dengan penyelenggaraan kegiatan alih teknologi. Tercapainya alih teknologi dapat dilakukan dengan lisensi wajib paten, joint venture atau mekanisme lain, sehingga aliran teknologi yang dihasilkan oleh negara maju ke negara berkembang akan menjadi lebih mudah untuk diawasi sehingga dapat mendorong proses terjadinya alih teknologi ${ }^{5}$ Paten

3 Hadi Kardoyo, Kebijakan Paten dan Inovasi : Sebuah Pengantar, (Jakarta : Pusat Penelitian Perkembangan Iptek (PAPPIPTEK) Lembaga IImu Pengetahuan Indonesia (LIPI) Press, 2010), hlm. 6.

4 Direktorat Jenderal Kekayaan Intelektual, Laporan Tahunan Direktorat Jenderal Kekayaan Intelektual Tahun 2018, (Jakarta : Direktorat Jenderal Kekayaan Intelektual, 2018), hlm. 54.

5 Niken Sari Dewi dan Suteki, Obstruksi Pelaksanaan lisensi Wajib Paten dalam Rangka Alih Teknologi pada Perusahaan Farmasi di Indonesia, Jurnal Law Reform 
merupakan hasil kekayaan intelektual yang berasal dari penyelenggaraan alih teknologi melalui kegiatan riset dan pengembangan. Di sisi lain, terdapat problematika yuridis yang terdapat dalam UU Paten berkaitan kegiatan alih teknologi. Problematika yuridis tersebut terdapat dalam ketentuan Pasal 20 UU Paten yang berbunyi:

(1) Paten wajib dilaksanakan di Indonesia;

(2) Pelaksanaan Paten sebagaimana dimaksud pada ayat (1), yaitu:

a. Pelaksanaan Paten-produk yang meliputi membuat, mengimpor, atau melisensikan produk yang diberi Paten;

b. Pelaksanaan Paten-proses yang meliputi membuat, melisensikan, atau mengimpor produk yang dihasilkan dari proses yang diberi Paten; atau

c. Pelaksanaan Paten-metode, sistem, dan penggunaan yang meliputi membuat, mengimpor, atau melisensikan produk yang dihasilkan dari metode, sistem, dan penggunaan yang diberi Paten.

Problematika pada pasal tersebut terjadi pada pemegang paten oleh pihak asing dimana berdasarkan ketentuan pasal tersebut menghambat kelancaran usahanya dan bertentangan dengan salah satu asas hukum benda, yakni droit de suite. Asas tersebut merupakan salah satu prinsip

Universitas Diponegoro Semarang. Vol. 13 No. 1, 2017, hlm. 10. dalam hukum benda yang berarti bahwa hak itu terus mengikuti bendanya, dimanapun (dalam tangan siapapun juga) benda itu berada serta hak itu terus mengikuti orang yang memilikinya. ${ }^{6}$ Hak kebendaan merupakan hak absolut, artinya hak yang melekat pada suatu benda memberikan kekuasaan langsung atas benda tersebut serta dapat dipertahankan terhadap tuntutan oleh setiap orang. Secara lebih lanjut, dikhawatirkan apabila pemegang paten asing tidak melaksanakan patennya di Indonesia. Dalam ketentuan regulasi baru diundangkan, yakni UndangUndang Nomor 11 Tahun 2019 tentang Sistem Nasional Ilmu dan Pengetahuan (untuk selanjutnya disebut UU Sisnas Iptek), mengatur bahwasannya Lembaga penelitian dan pengembangan teknologi asing wajib melakukan alih teknologi yang melakukan riset dan pengembangan di Indonesia sebagaimana implikasi dari Pasal 20 UU Paten tersebut.

Penelitian sejenis telah dilakukan oleh peneliti sebelumnya antara lain Anis Roisah yang kajian penelitiannya pada aspek alasan hukum pembentukan Pasal 20 UU Paten di Indonesia. Hasil dari penelitian tersebut bahwa aturan tersebut diharapkan dapat mempermudah dalam

${ }^{6}$ Sri Soedewi Masjchoen Sofwan, Hukum Perdata: Hukum Benda, (Yogyakarta : Liberty, 2008), hlm.25. 
melihat kualitas barang yang dihasilkan apakah sesuai dengan didaftarkan atau tidak. Ketentuan tersebut secara otomatis akan membukakan lapangan pekerjaan yang bisa menyerap tenaga kerja Indonesia. Selain itu, investasi yang datang ke Indonesia juga diharapkan akan semakin bertambah banyak, atau pemasukan lain seperti pajak dan lain sebagainya. $^{7}$

Muh Ali Masnun yang fokus penelitiannya lebih kepada aspek pengaturan kewajiban pemegang paten untuk membuat produk atau menggunakan proses di Indonesia ${ }^{8}$ memperoleh sebuah simpulan bahwa pengaturan kewajiban bagi pemegang paten dalam hal melaksanakan paten produk dan proses masing sangat sumir. Hal tersebut dibuktikan dengan belum jelasnya waktu dimulainya pelaksanaan paten, lingkup dan jenis paten yang wajib dilaksanakan, pengaturan penundaan pelaksanaan yang tidak disertai dengan ketentuan berupa

7 Anis Roisah, Alasan Hukum Pembentukan Pasal 20 UU Paten Di Indonesia, Tesis, (Yogyakarta : Universitas Islam Indonesia, 2019), hlm. 75.

8 Muh Ali Masnun dan Dina Roszana, Persoalan Pengaturan Kewajiban Pemegang Paten untuk Membuat Produk atau Menggunakan Proses di Indonesia, Jurnal Ius Quia Iustum Universitas Islam Indonesia. Vol 26 No. 2, 2019, hlm. 326348. kriteria (alasan) mengenai dapat atau tidaknya dilakukan penundaan, pengaturan batas waktu pengajuan permohonan penundaan yang tidak memerhatikan durasi pelindungan paten, tidak adanya ketentuan antisipatif untuk mengatasi kondisi apabila permohonan penundaan tidak disetujui oleh Menteri, serta pengaturan perpanjangan penundaan yang tidak disertai dengan ketentuan batas waktu dan kriteria (alasan) dapat atau tidaknya dilakukan perpanjangan penundaan.

Berbeda dengan penelitian sejenis yang telah dipaparkan, pada penelitian ini bertujuan untuk menganalisis implikasi kewajiban pelaksanaan paten terhadap penyelenggaraan alih teknologi dikaitkan dengan asas hukum benda yakni droit de suite yang artinya bahwa hak itu terus mengikuti bendanya.

\section{B. Metode Penelitian}

Permasalahan dalam artikel ini menggunakan metode penelitian hukum normatif yang sering dipakai sebagai lawan dari metode penelitian empiris/sosiologis. Penelitian normatif merupakan sebuah penelitian hukum yang bersifat murni yang dilakukan untuk menelitia suatu norma (sehingga disebut 
normatif). ${ }^{9}$ Bahan hukum yang digunakan berupa bahan hukum primer maupun bahan hukum sekunder ${ }^{10}$. Bahan hukum primer dalam penelitian ini berupa bahan autoritatif yang berkaitan dengan paten, antara lain UU Paten dan UU Sisnas Iptek. Bahan hukum sekunder adalah bahan hukum yang digunakan untuk menjelaskan bahan hukum primer yang berupa jurnal maupun buku-buku terkait. Adapun pendekatan yang digunakan berupa pendekatan perundang-undangan (statue approach) dan pendekatan konsep (conceptual approach). Analisis bahan hukum yang digunakan dengan analisis kualitatif dengan memberikan gambaran (deskripsi) dengan kata-kata atas temuantemuan, dan karenanya lebih mengutamakan mutu/kualitas dan bukan kuantitas. ${ }^{11}$

\section{Pembahasan}

Teknologi saat ini menjadi kebutuhan vital negara berkembang seperti

9 Munir Fuady, Metode Riset Hukum Pendekatan Teori dan Konsep, (Jakarta : Rajawali Pers, 2018), hlm. 130.

10 Peter Mahmud Marzuki, Penelitian Hukum Edisi Revisi, (Jakarta : Kencana, 2017), hlm. 181.

11 Salim HS dan Erlies Septiana Nurbaini, Penerapan Teori Hukum pada Penelitian Tesis dan Disertasi. (Jakarta : Rajawali Pers, 2014). HIm. 19.
Indonesia dalam mendukung pembangunan nasional. Indonesia yang masih memiliki berbagai keterbatasan dalam hal sumber daya manusia, riset dan pengembangan, serta penguasaan teknologi yang tergolong dapat dikatakan relatif masih rendah mengakibatkan adanya ketergantungan teknologi pada negara-negara maju. Ketergantungan tersebut dikarenakan munculnya hambatan-hambatan dalam penguasaan teknologi yang dihadapi oleh negara berkembang termasuk Indonesia sebagaimana dilontarkan oleh Sumantoro dalam Irawan antara lain $:^{12}$ 1) terdapat ketidaksempurnaan pasar teknologi dalam negeri, 2) kurangnya pengalaman dan keterampilan suatu negara yang menjadi penerima teknologi untuk menegosiasikan isi kontrak agar dapat mengalihkan teknologi yang dimiliki, 3) sikap pemerintah dalam mempengaruhi alih teknologi, dan 4) tingginya biaya untuk

${ }^{12}$ Candra Irawan, Aturan Alih Teknologi dari Perusahaan Swasta Kepada Perusahaan Nasional Pada Kegaiatan Penanaman Modal Untuk Percepatan Penguasaan Teknologi Maju Di Indonesia, Prosiding Seminar Nasional Multi Disiplin IImu \& Call For Papers Unisbank (Sendi-U) Ke-2 Tahun 2016 Kajian Multi Disiplin IImu dalam Pengembangan IPTEKS Untuk Mewujudkan Pembangunan Nasional Semesta Berencana (PNSB) sebagai Meningkatkan Daya Saing Global, (Semarang : Unisbank, 2016), hlm. 438. 
mendapatkan alih teknologi dari negara maju.

Ketergantungan teknologi yang tinggi oleh negara terhadap negara maju mengakibatkan negara berkembang harus mengeluarkan nominal yang tinggi untuk membayar teknologi yang digunakan dari negara lain. Hal ini mengakibatkan adanya ketidaksempurnaan serta tidak berkembangnya pasar teknologi dari dalam negeri dikarenakan belum cukup memadai untuk menunjang pengembangan riset dan masih bergantung pada teknologi yang dimiliki oleh negara lain. Terkait dengan kontrak alih teknologi yang dilakukan oleh negara berkembang dengan negara maju, sejauh ini negara berkembang khususnya Indonesia belum banyak berperan dalam percepatan penguasaan teknologi terbaru. Kontrak lisensi yang dilakukan secara privat memperkuat kedudukan pihak asing dalam pembuatan kontrak lisensi dibandingkan dengan pihak nasional, sehingga isi kontak lebih melindungi kepentingan pihak asing khususnya terkait dengan perlindungan terhadap teknologi (Hak Kekayaan Intelektual) yang dimiliki. Sebagai dampaknya, negara berkembang yang kurang pengalaman serta keterampilan negosiasi kontrak terkait alih teknologi agar dapat dialihkan, masih sangat memiliki ketergantungan terhadap teknologi pihak asing tanpa mampu membuat produk substansinya berdasarkan lisensi di dalam negeri. Sikap pemerintah negara berkembang dalam mempengaruhi alih teknologi dari negara asing sejauh ini telah dilakukan dengan membentuk regulasi tentang alih teknologi seperti pengaturan alih teknologi yang termuat dalam UU Sisnas Iptek. Sampai saat ini belum ada peraturan yang spesifik mengatur tentang alih teknologi di Indonesia sehingga menjadi hambatan bagi pelaksanaan proses alih teknologi dari negara maju untuk dapat diterapkan di Indonesia. Faktor penghambat lain adalah tingginya biaya untuk mendapatkan alih teknologi dari negara maju. Negara berkembang memerlukan teknologi untuk pembangunan ekonomi negaranya, sedangkan negara maju berkepentingan dalam perluasan teknologi serta hasil industrinya $^{13}$. Tingginya biaya yang dikeluarkan oleh negara berkembang untuk melakukan proses alih teknologi dari negara maju, mengakibatkan negara berkembang tidak dapat terlepas dari bantuan teknologi negara maju untuk menyelesaikan setiap permasalahan nasional tanpa adanya pengalihan teknologi maupun know-how.

${ }^{13}$ Ok. Saidin, Aspek Hukum Hak Kekayaan Intelektual (Intlelectual Property Rights), (Jakarta : PT. Raja Grafindo Persada, 2013), hlm. 314 
Undang-Undang Nomor 11 Tahun 2019 Tentang Sistem Nasional Ilmu Pengetahuan dan Teknologi (UU Sisnas Iptek) merupakan salah satu instumen hukum yang dijadikan sebagai dasar pengaturan alih teknologi di Indonesia yang memberikan pengaturan bahwa kegiatan alih teknologi tidak hanya berkaitan dengan hasil kekayaan intelektual yang dihasilkan oleh Perguruan Tinggi dan Lembaga Penelitian dan Pengembangan Indonesia, melainkan juga meliputi kebutuhan alih teknologi dari kekayaan intelektual yang dimiliki oleh negara asing dan negara maju untuk diterapkan di Indonesia. Alih teknologi yang diharapkan tidak hanya meliputi pemindahan atau pemasukan teknologi dari suatu negara ke negara lain, melainkan juga menyangkut kemampuan untuk memahami, memanfaatkan, menguasai dan mengembangkannya ${ }^{14}$.

Terminologi teknologi dalam UU Sisnas Iptek diatur dalam Pasal 1 angka 3 yaitu cara, metode, atau proses penerapan dan pemanfaatan berbagai disiplin ilmu pengetahuan yang bermanfaat dalam pemenuhan kebutuhan, kelangsungan, dan peningkatan kualitas kehidupan manusia. Salah satu upaya dalam proses penerapan

\footnotetext{
${ }^{14}$ Etty Susilowati, Kontrak Alih Teknologi pada Industri Manufaktur, (Yogyakarta : Genta Press, 2007), hlm. 13.
}

dan pemanfaatan teknologi dilakukan dengan alih teknologi. Pengertian alih teknologi dalam UU Sisnas Iptek diatur dalam Pasal 1 angka 15 yang memberikan definisi alih teknologi sebagai pengalihan kemampuan memanfaatkan dan menguasai ilmu pengetahuan dan teknologi antar lembaga, badan, atau orang baik yang berada dalam lingkungan dalam negeri maupun yang berasal dari luar negeri kedalam negeri atau sebaliknya. Pelaksanaan alih teknologi secara lebih lanjut diatur dalam Pasal 18 ayat (3) yang menyatakan bahwa:

(3) Alih teknologi sebagaimana dimaksud pasal ayat (1) dilaksanakan melalui :

a. lisensi;

b. kerjasama;

c. pelayanan jasa Ilmu Pengetahuan dan Teknologi; dan/atau

d. pelaksanaan Alih Teknologi yang dilakukan dengan tidak bertentangan dengan ketertiban umum dan ketentuan peraturan perundang-undangan."

Berdasarkan ketentuan tersebut, bahwa salah satu cara (mekanisme) alih teknologi dapat dilakukan melalui kerjasama. Pengalihan ilmu pengetahuan dan teknologi antar lembaga, badan, dan orang baik dari dalam maupun luar negeri dengan tujuan alih teknologi dapat dilakukan melalui kerjasama khususnya berkaitan dengan riset dan pengembangan. Riset dilaksanakan untuk penguatan 
penguasaan ilmu dasar dan ilmu terapan, termasuk didalamnya ilmu sosial yang digunakan untuk menciptakan dan/atau mengembangkan Ilmu Pengetahuan dan Teknologi.

Bahwa dalam hal pengembangan dilaksanakan sebagai tindak lanjut dari penelitian untuk meningkatkan kesejahteraan masyarakat dan memajukan peradaban. Alih teknologi dalam bidang penelitian dan pengembangan yang dapat dilakukan dengan cara kerjasama ditegaskan juga dalam Pasal 20 Peraturan Pemerintah Nomor 20 Tahun 2005 Tentang Alih Teknologi Kekayaan Intelektual Serta Hasil Kegiatan Penelitian Dan Pengembangan Oleh Perguruan Tinggi Dan Lembaga Penelitian Dan Pengembangan, yang menyatakan bahwa :

"Alih teknologi kekayaan intelektual serta hasil kegiatan penelitian dan pengembangan oleh perguruan tinggi dan lembaga litbang dilaksanakan melalui mekanisme:

a. lisensi;

b. kerjasama;

c. pelayanan jasa ilmu pengetahuan dan teknologi; dan/atau

d. publikasi."

Kegiatan riset dan pengembangan dalam rangka alih teknologi memerlukan kerjasama dengan pihak asing atau badan maupun lembaga penelitian dan pengembangan asing untuk menghasilkan suatu invensi dan inovasi yang mampu menyerap modal dan mempercepat proses alih teknologi di Indonesia. Alih teknologi dengan jalan kerjasama antara lembaga riset dan pengembangan Indonesia dengan pihak asing dapat dilakukan baik di dalam maupun di luar negeri sesuai dengan Perjanjian Internasional Agreement on Trade-Related Aspects of Intelectual Property Rights (TRIPS) sebagai salah satu kesepakatan dalam paket World Trade Organization (WTO). Article 27 patents shall be available and patent rights enjoyable without discrimination as to the place of invention, the field of technology and whether products are imported or locally produced. Terjemahan bebasnya : bahwa paten harus tersedia dan hak paten dinikmati tanpa diskriminasi berkaitan dengan tempat ditemukannya, bidang teknologi dan apakah tersebut diimpor atau di produksi di tingkat lokal.

Berdasarkan ketentuan Pasal 20 ayat (1) UU Paten, bahwa Paten wajib dilaksanakan di Indonesia. Ketentuan Pasal 20 tersebut salah satunya dimaksud dari kegiatan pelaksanaan paten di Indonesia salah satu diantaranya harus menunjang transfer teknologi. Pembentuk undang-undang sudah tepat dalam merumuskan ketentuan tersebut, salah satunya untuk melindungi kepentingan bangsa Indonesia salah satunya melalui alih teknologi. Alih teknologi sangat 
dibutuhkan dalam menunjang perkembangan teknologi di Negara Indonesia yang sangat jauh tertinggal oleh negara-negara lainnya yang memiliki keunggulan dalam bidang teknologi.

Negara berkembang termasuk Indonesia, lebih senang melakukan produksi barang yang dapat dipatenkan atau melakukan proses yang dipatenkan di dalam negeri untuk meningkatkan nilai tambah di negara sendiri. Nilai tambah yang dimaksud meliputi penggunaan bahan baku tenaga kerja, dan meningkatkan keterampilan sumber daya manusia dalam negeri. Dalam rangka melindungi kepentingan nasional, pemerintah melakukan perhitungan laba investor asing apabila pemegang paten asing membuat produk atau proses paten di negaranya sendiri sehingga pemerintah melakukan pembatasan-pembatasan tertentu salah satunya dengan adanya ketentuan Pasal 20 ayat (1) UU Paten.

Kenyataan ini berbanding terbalik dengan pemahaman alih teknologi dari negara maju atau negara industri dimana negara industri lebih senang melakukan pengerjaan paten di negerinya sendiri atau di negara industri maju lainnya yang kemudian hasilnya dipasarkan dinegara berkembang. Hal tersebut dikarenakan negara industri cenderung menekan agar biaya produksi yang dikeluarkan lebih rendah, investasi lebih menguntungkan, pemasaran akan lebih luas, efisiensi produk yang dipatenkan lebih tinggi, dan memperoleh keuntungan (laba) besar apabila dibandingkan dengan melakukan produksi di negara berkembang. Namun meskipun demikian, jarang terjadi paten asing yang dapat dikerjakan sendiri oleh negara berkembang tanpa bantuan teknik dan know-how dari pemilik paten asing yang bersangkutan.

Permasalahan lain muncul dengan adanya ketentuan dalam Pasal 20 UU Paten. Disisi lain juga paten merupakan hak kebendaan, yakni hak mutlak yang diberikan negara kepada penemunya dan dapat dipertahankan terhadap siapapun juga. Pada dasarnya prinsip semua jenis Hak Kekayaan Intelektual, termasuk Paten masuk ke dalam ruang lingkup hukum benda. Hal tersebut dengan merujuk pada ketentuan Pasal 503 BW yang mengatur bahwa ketentuan wujud benda diklasifikasi menjadi 2 (dua) jenis yakni yakni benda berwujud (material) dan benda tidak berwujud (immaterial). Benda tidak berwujud ini adalah yang sebagaimana termaktub dalam ketentuan Pasal 499 BW disebut hak, sebagai contoh hak adalah hak tagih, hak guna usaha, hak tanggungan, dan Hak Kekayaan Intelektual. Sederhananya, Hak Kekayaan Intelektual dapat menjadi objek hak, apalagi jika ikut 
serta dimanfaaatkan oleh pihak lain melalui lisensi. ${ }^{15}$

Berkaitan dengan hak kebendaan, khususnya Hak Kekayaan Intelektual jenis paten melekat juga azas Droit de Suite, hak yang mengikuti dimana pun benda itu berada. Jika seseorang memiliki paten (pihak asing) juga akan dilindungi setelah memenuhi persyaratan pendaftarannya. Dalam ketentuan yang dicantumkan dalam Pasal 20 UU Paten merupakan pengecualian dari azas droit de suite. Ketentuan dalam Pasal 20 UU Paten dianggap bertentangan dengan azas droit de suite dalam hukum benda. Akan tetapi dalam merumuskan regulasi, pembentuk undang-undang tidak saja memperhatikan kebutuhan dan kepentingan bangsa namun juga mendengarkan keluhan dari pihak asing. Hal ini dikarenakan, hak paten bersifat eksklusif karena hanya diberikan kepada inventor untuk melaksanakan sendiri hasil penemuannya serta memberikan persetujuan kepada orang lain untuk melaksanakan hasil invensinya. Dengan kata lain, orang lain hanya dapat menggunakan invensinya tersebut apabila

15 Abdulkadir Muhammad, Kajian Hukum Ekonomi Hak Kekayaan Intelektual, (Bandung : Citra Aditya Bakti, 2008), hlm. 3. ada persetujuan atau izin dari inventor selaku pemilik hak paten ${ }^{16}$.

Salah satu usaha mengenai paten asing yang tidak dikerjakan di dalam negeri adalah dengan memberlakukan "compulsory licencing" yaitu suatu keadaan dimana pemerintah mengizinkan pihak lain untuk memproduksi invensi (produk maupun proses) yang telah dipatenkan tanpa persetujuan dari pemegang paten. ${ }^{17}$ Pemberlakuan tersebut merupakan salah satu bentuk fleksibelitas dalam perlindungan paten yang termuat dalam Perjanjian World Trade Organization (WTO) terkait Hak Kekayaan Intelektual dalam TRIPs Agreement. Upaya pemerintah negara berkembang ialah memberikan pemilik asing suatu hak yang didahulukan untuk mengerjakan patennya di negara berkembang. Hal ini tidak hanya membawa konsekuensi tambahan biaya penelitian dan pengembangan, melainkan ketergantungan negara berkembang karena

16 Rinayah Nasir, Paten dalam Proses Produksi : Tinjauan Hak yang Melekat pada Inventor, Jurnal Hukum POSITUM. Vol. 1 No. 1, Desember, 2016, hlm. 145

17

Sri Winarti, The Legal Implication Of Compulsory Licence Pharmceutical Products In The TRIPs Agreement To The Protection Of The Right To Health In Developing Countries, Jurnal Dinamika Hukum Universitas Jendral Soedirman. Vol. 18 No. 1, Januari, 2018, hlm.3. 
bertambahnya investasi dan modal sehingga paten asing tidak hanya meningkatkan ekonomi melainkan juga meningkatkan kecerdasan negara berkembang.

Akibat hukum yang timbul dari ketentuan Pasal 20 UU Paten adalah sanksi yang dikenakan kepada pemegang paten apabila tidak menjalankan atau melanggar ketentuan tersebut yang diatur dalam Pasal 132 ayat (4) UU Paten bahwa jaksa atau pihak lain yang mewakili kepentingan nasional berhak mengajukan gugatan penghapusan Paten terhadap Pemegang Paten. Akibat non hukum yang kemungkinan timbul berkaitan dengan Pasal 20 UU Paten adalah adanya kecenderungan pihak asing yang menolak untuk mendaftarkan patennya di Indonesia. Menyikapi hal tersebut, pemerintah dapat memberi ruang kepada pemegang paten asing untuk tidak serta merta memenuhi kewajiban dalam ketentuan Pasal 20 UU Paten tersebut atau dapat membuat peraturan pemerintah untuk pengecualian pemberlakuan Pasal 20 UU Paten atau diadakan amandemen Pasal 20 UU Paten dengan perubahan kecil. Misalnya, bagi pemegang paten yang terdaftar di Indonesia, apabila sedang melakukan produksi atau membuat proses di luar negeri diwajibkan memberikan kompensasi lain di Indonesia yang peruntukkannya atau besarannya akan diatur dalam peraturan pemerintah. Peruntukan sebagaimana dimaksud dapat digunakan untuk kepentingan lembaga penelitian atau pengembangan untuk percepatan dan seterusnya. Sebagaimana dalam ketentuan UU Sisnas Iptek, Pasal 76 huruf e, yang menyatakan bahwa :

"Kelembagaan Ilmu Pengetahuan dan Teknologi Asing dan/atau orang Indonesia sebagaimana dimaksud dalam Pasal 75 yang melakukan Penelitian, Pengembangan, Pengkajian, dan Penerapan dengan dana yang bersumber dari pembiayaan asing, dalam melakukan Penelitian, Pengembangan, dan Pengkajian, dan Penerapan di Indonesia wajib :

e. melakukan alih teknologi

Beranjak dari ketentuan Pasal 76 huruf UU Sisnas Iptek, agar kiranya dapat diberikan pengaturan yang bersifat pengecualian terkait pemegang paten yang berbentuk Lembaga Ilmu Pengetahuan dan Teknologi agar dapat melakukan kewajiban terkait membuat produk atau menggunakan proses di Indonesia untuk menunjang transfer teknologi. Perlu kiranya diberikan perhatian khusus dalam bidang Penelitian, Pengembangan, Pengkajian, dan Penerapan Teknologi yang dilakukan oleh Lembaga Ilmu Pengetahuan dan Teknologi sebagai wujud pengecualian agar dapat melaksanakan 
kewajiban sebagaimana yang diamanatkan dalam Pasal 20 UU Paten.

\section{Kesimpulan}

Berdasarkan uraian diatas, dapat ditarik kesimpulan bahwa alih teknologi dapat dilakukan dengan berbagai cara salah satunya dalam bentuk kerjasama dibidang penelitian dan pengembangan. Indonesia sebagai negara berkembang terdapat tuntutan untuk mensejajarkan Ilmu Pengetahuan dan Teknologi khususnya berkaitan dengan alih teknologi lebih banyak menekankan kepada kepentingan umum daripada kepentingan pribadi penemu paten (pembuat produk dan/atau penemu proses) asing dalam mengatur alih teknologi. Adanya unsur bantuan dari negara maju ke negara berkembang dalam proses alih teknologi menitikberatkan bahwa kepentingan negara berkembang lebih besar meskipun tidak mengabaikan kepentingan negara maju.

Ketentuan sebagaimana dimaksud dalam Pasal 20 UU Paten memerlukan pengecualian khusus bagi pemegang paten yang berbentuk Lembaga Ilmu Pengetahuan dan Teknologi agar dapat melakukan kewajiban terkait membuat produk atau menggunakan proses di Indonesia untuk menunjang transfer teknologi dalam hal pelaksanaan alih teknologi yang bekerjasama dengan badan dan/atau lembaga penelitian dan pengembangan asing. Pengecualian terhadap Pasal 20 UU Paten, adalah dengan memberi ruang kepada pemegang paten asing untuk tidak serta merta memenuhi kewajiban dalam Pasal 20 UU Paten tersebut. Langkah lain yang dapat ditempuh tanpa menghilangkan ketentuan Pasal 20 UU Paten tersebut antara lain mengadakan perubahan (amandemen) terhadap ketentuan Pasal 20 UU Paten dengan perubahan kecil. Misalnya bagi pemegang paten yang terdaftar di Indonesia, apabila sedang melakukan produksi atau membuat proses di luar negeri diwajibkan memberikan kompensasi lain di Indonesia yang peruntukkannya atau besarannya akan diatur dalam peraturan pemerintah agar dapat digunakan untuk kepentingan lembaga penelitian atau pengembangan untuk percepatan dan seterusnya. Dalam hal ini, kebijakan peraturan terkait dengan Hak Kekayaan Intelektual dan perdagangan perlu didesain ulang untuk melindungi dan memberikan respon terhadap persaingan global dengan memperhatikan kepentingan pribadi pemegang paten asing. 


\section{Daftar Pustaka}

\section{Buku}

Abdulkadir Muhammad, Kajian Hukum Ekonomi Hak Kekayaan Intelektual, Bandung : Citra Aditya Bakti, 2008.

Direktorat Jenderal Kekayaan Intelektual, Modul Kekayaan Intelektual di Bidang Paten, Jakarta : DJKI Kemenkumham, 2019.

Etty Susilowati, Kontrak Alih Teknologi pada Industri Manufaktur, Yogyakarta : Genta Press, 2007.

Hadi Kardoyo, Kebijakan Paten dan Inovasi : Sebuah Pengantar, Jakarta : Pusat Penelitian Perkembangan Iptek (PAPPIPTEK) Lembaga Ilmu Pengetahuan Indonesia (LIPI) Press, 2010.

Kementerian Riset, Teknologi, Dan Pendidikan Tinggi Republik Indonesia, Naskah Akademik Rancangan Undang-Undang Tentang Sistem Nasional Ilmu Pengetahuan Dan Teknologi, Jakarta: Kemenristekdikit, 2017.

Munir Fuady, Metode Riset Hukum Pendekatan Teori dan Konsep, Jakarta : Rajawali Pers, 2018.

OK. Saidin, Aspek Hukum Hak Kekayaan Intelektual (Intlelectual Property Rights), Jakarta : PT. Raja Grafindo Persada, 2013.

Peter Mahmud Marzuki, Penelitian Hukum Edisi Revisi, Jakarta : Kencana, 2017.

Salim HS dan Erlies Septiana Nurbaini, Penerapan Teori Hukum pada Penelitian Tesis dan Disertas. Jakarta : Rajawali Pers, 2014.
Sri Soedewi Masjchoen Sofwan, Hukum Perdata: Hukum Benda, Yogyakarta : Liberty, 2008.

\section{Karya Ilmiah}

Anis Roisah, Alasan Hukum Pembentukan Pasal 20 UU Paten di Indonesia, Tesis, Program Magister Ilmu Hukum Universitas Islam Indonesia, 2019.

Candra Irawan, Aturan Alih Teknologi dari Perusahaan Swasta Kepada Perusahaan Nasional Pada Kegaiatan Penanaman Modal Untuk Percepatan Penguasaan Teknologi Maju Di Indonesia, Prosiding Seminar Nasional Multi Disiplin Ilmu \& Call For Papers Unisbank (Sendi-U) Ke-2 Tahun 2016 Kajian Multi Disiplin Ilmu dalam Pengembangan IPTEKS Untuk Mewujudkan Pembangunan Nasional Semesta Berencana (PNSB) sebagai Meningkatkan Daya Saing Global, Semarang : Unisbank, 2016.

Muh. Ali Masnun dan Dilla Nurfiana Astanti, Urgensi Pembatasan Hak Eksklusif Paten Covid-19 Melalui Penerapan Lisensi Wajib di Indonesia, Jurnal Komunikasi Hukum (JKH) Universitas Pendidikan Ganesha. Vol. 6 No. 2, Agustus, 2020.

Muh Ali Masnun dan Dina Roszana, Persoalan Pengaturan Kewajiban Pemegang Paten untuk Membuat Produk atau Menggunakan Proses di Indonesia, Jurnal Ius Quia Iustum Universitas Islam Indonesia. Vol 26 No. 2, 2019.

Niken Sari Dewi dan Suteki, Obstruksi Pelaksanaan lisensi Wajib Paten dalam Rangka Alih Teknologi pada 
Perusahaan Farmasi di Indonesia, Jurnal Law Reform Universitas Diponegoro Semarang. Vol. 13 No. $1,2017$.

Sri Winarti, The Legal Implication Of Compulsory Licence Pharmceutical Products In The TRIPs Agreement To The Protection Of The Right To Health In Developing Countries, Jurnal Dinamika Hukum Universitas Jendral Soedirman. Vol. 18 No. 1, Januari, 2018.

Rinayah Nasir, Paten dalam Proses Produksi : Tinjauan Hak yang Melekat pada Inventor, Jurnal Hukum POSITUM. Vol. 1 No. 1, Desember, 2016.

\section{Peraturan Perundang - Undangan}

Undang-Undang Dasar Negara Republik Indonesia Tahun 1945.

Undang-Undang Nomor 13 Tahun 2016 Tentang Paten.

Undang-Undang Nomor 11 Tahun 2019 Tentang Sistem Nasional Ilmu Pengetahuan dan Teknologi. 